\title{
In utero exposure to cadmium pollution in Cairo and Giza governorates of Egypt
}

G. Mokhtar, ${ }^{\prime}$ E. Hossny, ${ }^{1}$ M. El-Awady² and M. Zekry'

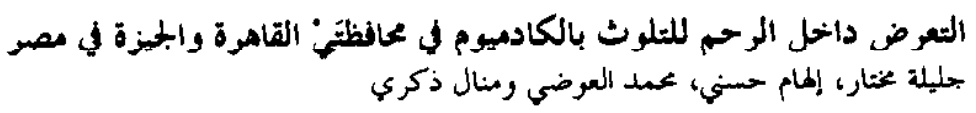

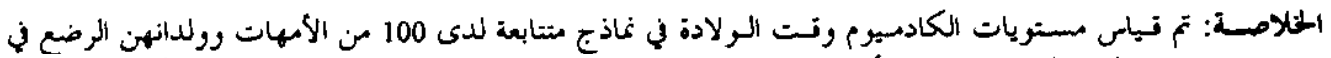

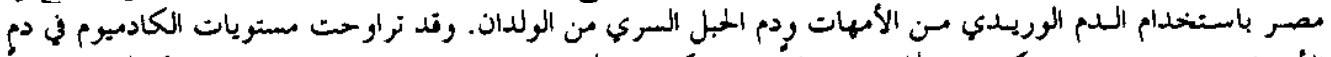

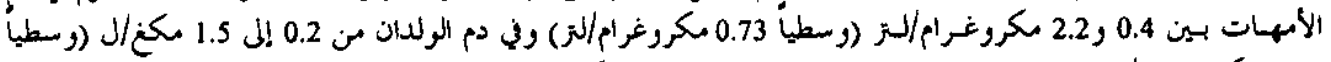

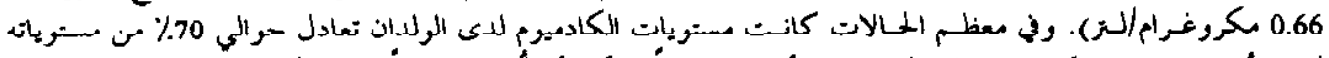

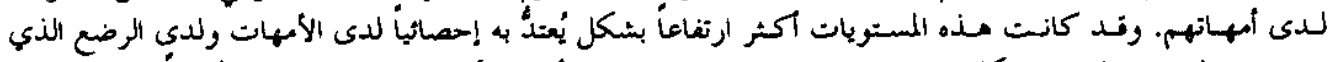

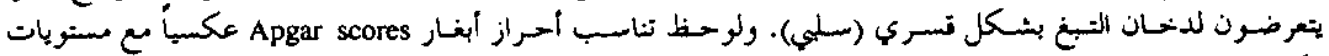

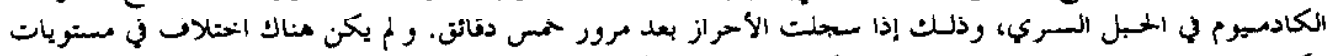

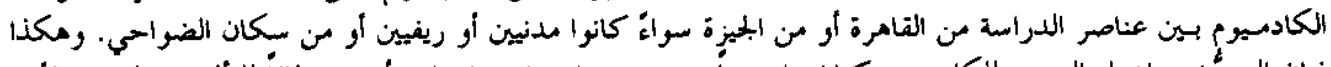

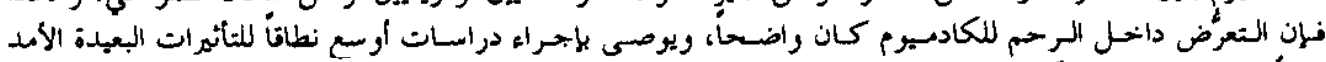

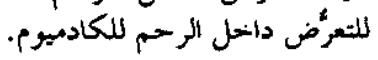

ABSTRACT Sorum cadmiLm levels at delivery were measured in a consecutive sample of 100 motherinfant pairs in Egypt using venous blood from mothers and umbilical cord blood from neonates. The serum cadmium levels of mothers ranged from 0.4 to $2.2 \mu \mathrm{g} / \mathrm{L}$ (mean $0.73 \mu \mathrm{g} / \mathrm{L}$ ) and of infants from 0.2 to $1.5 \mu \mathrm{g} / \mathrm{L}$ (mean $0.66 \mu \mathrm{g} / \mathrm{L}$ ). Infant cadmium levels were about $70 \%$ of maternal levels in most pairs. Serum cadmium was significantly higher in mothers and babies passively exposed to tobacco smoke. Five-minute Apgar scores were negatively correlated with cord blood cadmium levels. The cadmium levels did not differ between subjects from Cairo and Giza or according to urban, sububan or rural areas. Thus, in utero exposure to cadmilum was evident and wider-scale stugies on its iong-term efrects are recommended.

Exposition in utero à la pollution par le cadmium dans les gouvernorats du Caire et de Giza en Egypte

RESUME La concentration sérique de cadmium lors de l'accouchement a été mesurée dans un échantillon consécutif de cent paires mère-enfant en Egypte en utilisant le sang veineux des mères et le sang du cordon ombiliçal des nouveau-nés. La concentration sérique do cadmium dos mères ótait comprise entre 0,4 et $2,2 \mu \mathrm{g} / \mathrm{L}$ (moyenne $0,73 \mu \mathrm{g} / \mathrm{L}$ ) et celle des enfants entre 0,2 et $1,5 \mu \mathrm{g} / \mathrm{L}$ (moyenne $0,66 \mu \mathrm{g} / \mathrm{L}$ ). La concentration de cadmium chez les nouveau-nés était d'environ $70 \%$ de celle des mères dans la plupart des paires. Le cadmium sérique était significativement plus élevé chez les mères et les bébés exposés à la fumée de tabac. Le score d'Apgar à cinq minutes était corrélé de manière négative avec la concentration de cadmium dans le sang du cordon. La concentration de cadmium ne différait pas entre les sujets du Caire et de Giza, ou en fonction des zones urbaines, suburbaines ou rurales. Par conséquent, l'exposition in utero au cadmium était évidente, et de plus larges études sur les effets à long terme sont recommandées.

'Department of Paediatrics; 'Department of Community Medicine, Ain Shams University, Cairo, Egypt. Received: 22/01/01; accepled: 08/12/01 


\section{Introduction}

The worldwide expansion of industrialization and the inappropriate methods of waste disposal in some countries have led to an increased risk of human exposure to heavy metals. Cadmium is widely used in many industries. As a component of many alloys it is used in the manufacture of electroconductors and in electroplating. It is present in ceramics, pigments, dental prosthetics, plastic stabilizers and storage batteries. It is also a by-product of zinc smelting and is used in the photographic, rubber, motor and aircraft industries. Cadmium is emitted in industrial fumes and may contaminate the water supply in industrial areas [1]. It is a potentially neurotoxic pollutant [2] that is claimed to cause a slowly progressive and irreversible renal tubular dysfunction as well as respiratory complications [3].

Previous studies from other countries such as Sweden, Turkey, Singapore and Taiwan have documented the transplacental transfer of heavy metals including cadmium [4-7]. Hossny and colleagues [8], in their study of exposure to cadmium pollution of children in Cairo city and its suburbs, reported that venous blood cadmium levels were higher among neonates whose body weights and heights remained below the fifth percentiles for age. However, the relation between birth weight and cadmium levels in umbilical cord blood did not reach statistical significance in the study of Odland and associates [9].

We aimed to measure cadmium levels in mother-infant pairs at delivery in order to evaluate the exposure of pregnant women and their fetuses to this dangerous metal.

\section{Methods}

The study was conducted on 100 mothers and their live-born babies who were enrolled consccutively at delivery from the
Obstetric Department of Ain Shams Unjversity and the Al-Galaa Maternity Hospital in Cairo. The study sample comprised 59 mothers from Cairo and 41 from Giza governorates.

The maternal history was taken to establish: residency (urban, suburban or rural), maternal smoking status, as reported by the mother [smoker, passive smoker (defined as having at least one household member who smoked) or non-smoker], perinatal problems, morbidity or mortality in other babies and history of abortion. The neonatal factors recorded were: sex, gestational age, birth order, mode of delivery (vaginal or caesarean) and Apgar score at five minutes. The weight, crown-heel length, and skull circumference were measured at birth. Babies were also examined for congenital anomalies or any morbidity.

Blood was collected by venepuncture. from mothers and from the umbilical cord of babies at delivery. The serum was separated by centrifugation at $2000 \times \mathrm{g}$ and collected in clean metal-free tubes; haemolysed samples were discarded. Estimation of serum cadmium was performed in the Department of Community and Occupational Medicine, Ain Shams University, using flameless atomic absorption spectrophotometry (Perkin-Elmer 460, USA) [10].

The results were statistically analysed via a standard computer program (Statistica software package, StatSoft, Tulsa, Oklahoma, USA) using Student $(t)$, Wilcoxon rank $(z)$ and correlation coefficient $(r)$ tests. The data are presented as mean \pm standard deviation. Probability $(P)$ values were considered significant if less than 0.05 .

\section{Results}

The serum cadmium concentrations of the 100 mothers ranged from 0.4 to $2.2 \mu \mathrm{g} / \mathrm{L}$

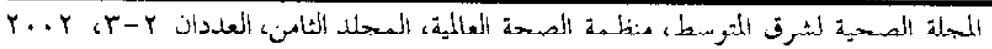


with a mean value of $0.7 \pm 0.3 \mu \mathrm{g} / \mathrm{L}$. The corresponding levels of their infants ranged from 0.2 to $1.5 \mu \mathrm{g} / \mathrm{L}$ with a mean of $0.7 \pm$ $0.2 \mathrm{mg} / \mathrm{L}$. The individual concentrations of the cord blood cadmium were about $70 \%$ of those of the maternal serum in most pairs. The difference between the mean values of mothers and babies was not sta+ tistically significant $(t=1.89, P>0.05)$.

On comparing serum cadmium levels according to maternal smoking status, the mean cadmium concentration was significantly higher in the 61 mothers who were passively exposed to tobacco smoke $(0.8 \pm$ $0.31 \mu \mathrm{g} / \mathrm{L})$ compared with the 38 nonsmokers $(0.6 \pm 0.14 \mu \mathrm{g} / \mathrm{L})$. Again, infants of passive smokers had cord blood cadmium concentrations that were significantly higher $(0.7 \pm 0.19 \mu \mathrm{g} / \mathrm{L})$ than those of nonsmokers $(0.5 \pm 0.14 \mu \mathrm{g} / \mathrm{L})$ (Figure 1). Only one mother admitted that she was an active smoker and her own $(1.9 \mu \mathrm{g} / \mathrm{L})$ and her infant's $(1.5 \mu \mathrm{g} / \mathrm{L})$ cadmium levels were relatively high.

The mean serum cadmium concentrations of the 59 mothers and babies from
Cairo $(0.7 \pm 0.3 \mu \mathrm{g} / \mathrm{L})$ were similar to the 41 subjects from Giza $(0.8 \pm 0.4 \mu \mathrm{g} / \mathrm{L} ; P>$ 0.05 ). The cadmium levels in the cord blood of Cairo infants $(0.6 \pm 0.3 \mu \mathrm{g} / \mathrm{L})$ were also similar to those of Giza infants $(0.7 \pm 0.2 \mu \mathrm{g} / \mathrm{L} ; P>0.05)$. More subjects lived in suburban $(n=64)$ than urban $(n=$ 32) areas; only four subjects lived in purely rural areas. There was no relationship between residential classification and serum cadmium levels.

The serum cadmiun concentrations in infants showed a negative correlation with their five-minute Apgar scores; thus the higher the cord bloud cadniun level the lower the Apgar score $(P<0.05$ ) (Figure 2). A positive correlation was also seen between the maternal and infant serun cadmium levels $(r=0.85, P<0.05$ ). There was no significant variation of the serum cadmium levels in mothers or babics according to perinatal obstetric history, sibling morbidity and mortality or mode of delivery (vaginal or caesarean). Mortover, the serum cadmium level could not be related by correlation coefficient to the birth or-

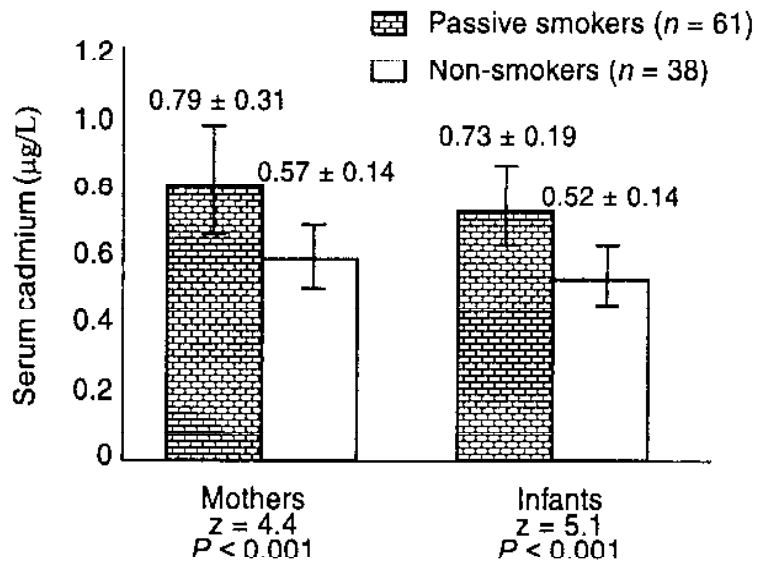

Figure 1 Serum cadmium concentrations of mothers and infants according to maternal smoking status 


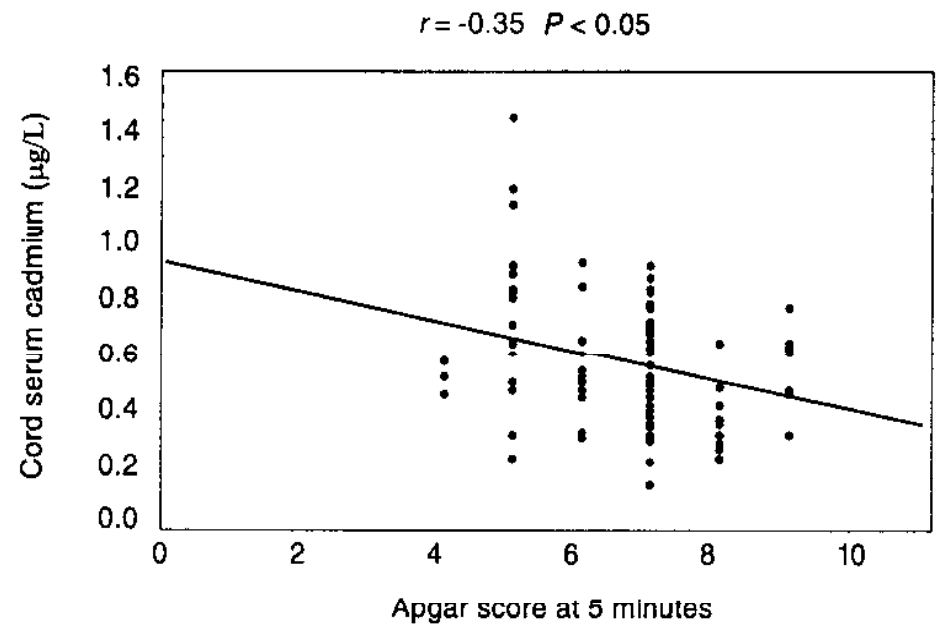

Figure 2 Negative correlation between infants' umbilical cord serum cadmium concentrations and Apgar scores at five minutes

der, gestational age, birth weight, crownheal length or skull circumference of the neonates $(P>0.05)$.

\section{Discussion}

The mean serum cadmium levels of mothers in this study were comparable to that of the cord blood of their babies. Howerer, the individual concentrations of the cord blood cadmium were about $70 \%$ of those of the maternal scrum in most pairs. This finding agrees with a Swedish study on the placental transfer of cadmium [4]. GaliciaGarcia and coworkcrs [II] suggested the existence of a placental barrier for cadmium in their study on 49 mothers and neonates from Mexico City.

None of the studied mothers was occupationally exposed to cadmium. Their exposure therefore probably resulted from the general environment. Air pollution with cadmium comes mainly from industrial fumes in the vicinity of homes or from to- bacco smoke indoors. The oral route is another important means of exposure and is due mainly to water and food pollution $[12,13]$. At $0.73 \mu \mathrm{g} / \mathrm{L}$ the mean serum cadmium of the studied mothers was high compared with a relevant study by Krachler and associates [5], who reported an average of $0.3 \mu \mathrm{g} / \mathrm{L}$ in the sera of mothers at delivery. The umbilical cord serum level in their series $(0.2 \mu \mathrm{g} / \mathrm{L})$ was also lower than in our study $(0.66 \mu \mathrm{g} / \mathrm{L})$. Studies on whole blood reveal different results, with levels ranging from $0.26 \mu \mathrm{g} / \mathrm{L}$ in mothers from Singapore [6] up to $1.3 \mu \mathrm{g} / \mathrm{L}$ in mothers from Taiwan and $0.78 \mu \mathrm{g} / \mathrm{L}$ in cord blood of their babies [7]. A relevant study on sub-Arctic and Arctic populations of Norway and Russia showed levels of 2.2 $\mathrm{nmol} / \mathrm{L}$ and $1.8 \mathrm{nmol} / \mathrm{L}$ in maternal and cord blood samples respectively [9].

The mother-infant paits in our study were living either in Cairo or Giza governorates, both places which contain plants and factories emitting industrial fumes. The 
serum cadmium levels did not vary according to the city of residence or urban/rural residential classification either in mothers or infants. Zielonka and Wodzien [14] reported that schoolchildren living in rural areas of Poland had higher levels of urinary cadmium than urban citizens. Poland and other countries of Central Europe have been found to have highcr cadmium pollution levels than Western European countries [2]. In Egypt many industries are located in Cairo and Giza. Other sources of exposure in our study might be through drinking water, which distributes cadmium remnants into homes; certainly cadmium pollution from industrial waste might be expected in the River Nile. Although exposure to cadmium pollution from drinking water has been considered unimportant in parts of the world such as Canada [12], it was found to be a significant risk in some areas of Poland [14]. The cadmium content of agricultural crops varies according to the species, scason and level of soil contamination. Even glazed ceramic food containers have been found to release cadmium into acidic foods [15].

Environmental tobacco smoke provides another source of exposure to cadmium, which is known to be deposited and concentrated in the leaves of the tobacco plant [16]. Therefore, active and passive smokers are more cxposcd to cadmium than non-smokers. In this study the serum cadmium levels of mothers and infants passivcly cxposed to tobacco smoke were significantly higher than the corresponding values for non-smokers. Moreover, the only mother who was an active smoker had high serum cadmium levels in her own and her neonate's serum, denoting significant cxposure. Willers and associates [17] stud ied the relationship between urinary cotinine as an indicator of exposure to nicotine and blood levels of some heavy metals in cluding cadmium. The serum cadmium was strongly associated with the urinary cotinine level. Children with high serum cadmium showed impairment of pulmonary function tests and the authors related this phenomenon to exposure to environmental tobacco smoke. Another study on cadmium levels in mother-newborn pairs found that the most important environmontal factor seemed to be smoking. Even so, the authors reported a significant increase in cadmium lcvels during pregnancy among non-smoking mothers, probably from industrial sources [4]. A similar finding was reported by Chia and associates [6] who observed significant levels of exposure to cadmium even in non-smoking men and women.

The umbilical cord blood cadmium concentrations were negatively correlated with babics' Apgar scores at five minutes. This may suggest that cadmium pollution affects the well-being of babies immediately following birth. Such a finding might be simply explained by the direct vasoconstrictive effect of cadmium on the placental blood ressels disturbing the thromboxane A2/prostacyclin ratio and contributing to some sort of placental insufticiency. Because it is associated with renal impairment [1] and alteration of pulmonary function [17], cadmium exposure during pregnancy would be expected to raise the necessity for neonatal resuscitation following birth. Other reported effects of cadmium during pregnancy include maternal hypertension, placental vasoconstriction and neurotoxicity $[2,18]$. The relation between cadmium and Apgar scoring might also be a direct consequence of tobacco smoke exposure. Passive smoking, as documented by cord blood cotinine levels, did alter the Apgar scores and birth weights of neonates in the study of Hossny and associates [19]. This might be explained by the vasoconstrictive 
effect of tobacco smoke on stem villous arteries compromising the fetal placental blood flow [20]. The strong relation between tobacco smoke and cadmium levels may suggest that the Apgar score defect observed in our study could be a result of exposure to either or both factors together. Wider-scale studies are needed to separate the effect of these pollutants on pregnancy outcome.

It is worth mentioning that maternal serum or cord blood eadmium levels could not be correlated to the growth parameters of the infants such as the birth weight, length and skull circumference. A study on 50 consecutive mother-infant pairs from three Russian and three Norwegian communities failed to find any correlation between maternal blood cadmium and birth weight [9]. However, the effect on growth might again need to be assessed in larger scale studies.

\section{Conclusions and} recommendations

We recommend further studies on the longterm effects of in utero exposure to cadmium pollution and on the objective relation between cadmium levels and tobacco smoke exposure. Field studies on cadmium distribution in the Egyptian environment would be worthwhile, so too would be the estimation of serum cadmium levels in various age groups in all localities of Egypt. We also suggest that exposure of fetuses to the hazards of cadmium pollution could be decreased through systematized scientifically-based efforts towards proper disposal of cadmium waste and reduction of industrial emissions as well as the prevention of smoking in public places.

\section{References}

1. Robertson WO. Chronic poisoning. Trace metal poisoning - cadmium. In: Russell LC, Goldman L, Bennett JC, eds. Cecil textbook of medicine, 21st ed. Philadelphia, wB Saunders Company, 2000:74.

2. Janousek $V$ et al. Cord blood levels of potentially neurotoxic pollutants (polychlorinated biphenyls, lead and cadmium) in the areas of Prague (Czech Republic) and Katowice (Poland). Comparison with reference values in the Netherlands. The Czech/Polish/Dutch/ German Research Team. Central Europoan journal of public health, 1994, $2(2): 73-6$.

3. Iwata $\mathrm{K}$ et al. Renal tubular function after reduction of env|ronmental cadmium exposure: a ten years follow up. Archives of environmental health, 1993, 48(3):15763.
4. Lagerkvist BJ et al. Placental transfer of cadmium. IARC scientific publications, 1992, (118):287-91.

5. Krachler M, Rossipal E, Micetic-Turk D. Trace element transfer from the mother to the newborn: investigations on triplets of colostrum, maternal and umbilical cord sera. European journal of clinical nutrition, 1999, 53(6):486-94.

6. Chia SE et al. Blood cadmium levels in non-occupationally exposed adult subjects in Singapore. Science of the total environment, 1994, 145(1-2):119-23.

7. Soong $Y K$ et al. Lead, cadmium, arsenic and mercury levels in maternal and fetal cord blood Journal of the Formosan Medical Association, 1991, 90(1):5965. 
8. Hossny $E$ et al. Environmental exposure of the pediatric age groups in Cairo city and its suburbs to cadmium pollution. Science of the total environment, 2001, 273:135-46.

9. Odland JO et al. Blood lead and cadmium and birth weight among subarctic and arctic populations of Norway and Russia. Acta obstetricia et gynecologica scandinavica, 1999, 78(10):852-60.

10. Roberts $C A$, Clark JM. Improved determination of oadmium in blood and plasma by flameless atomic absorption spectroscopy. Bulletin of environmental contamination and toxicology. 1986. 36(4):496-9.

11. Galicia-Garcia $V$ et al. Cadmium levels in matornal, cord and newborn blood in Mexico City. Toxicology letters, 1997, 91(1):57-61.

12. Meranger JC, Subramanian KS, Chalifoux $\mathrm{C}$. Heavy metals and other elements: a survey for cadmium, cobalt, chromium, copper, nickel, lead, zinc, calcium and magnesium in Canadian drinking-water supplies. Journal of the Association of Official Analytical Chemists, $1981,64: 44-53$.

13. Sapunar-Postruznik $J$ et al. Estimation of dietary intake of lead and cadmium in the general population of Croatia. Science of the total environment, 1996 , $177(1-3): 31-5$
14. Zielonka $E$, Wodzien M. Blood cadmium and lead levels among school children in Cracow. Folia medica Cracoviensia. 1993, 34(1-4):85-96.

15. Beckman 1 et al. Release of lead and cadmium from glazod and enamelled food ware. Var foda, 1979, 31:93-7.

16. Friberg L. Cadmium in the environment, 2nd ed. Cleveland, CRC Press, 1974:48.

17. Willers $S$ at al. Exposure to environmental tobacco smoke in the household and urinary cotinine excretion, heavy metals retention, and lung function. Archives of environmental health, 1992, 47(5):35763.

18. Eisenmann CJ, Miller PK. Cadmium and glutathion: effect on human placental thromboxane and prostacyclin production. Reproductive toxicology, 1995, 9(1): 41-8.

19. Hossny $E_{1}$ Hosni A, Mabrouk R. In utero exposure to tobacco smoke. Egyptian medical joumal, 1994, 11(12):409-16.

20. Clausen HV, Jorgensen JC, Ottesen B. Stem villous arteries from the placentas of heavy smokers: functional and mechanical properties. American journal of obstetrics and gynecology, 1999, $180(2$ pt 1):476-82. 